\title{
Pengaruh Penambahan Serbuk Tongkol Jagung pada Pembuatan Biobriket dari Pelepah Pisang dengan Perekat Tetes Tebu
}

\author{
Dini Kurniawati ${ }^{a}$, Noor Diansyah Januardi ${ }^{b}$, Nur Subekhi ${ }^{c}$ \\ a,b,c Jurusan Teknik Mesin, Fakultas Teknik, Universitas Muhammadiyah Malang \\ Jl. Raya Tlogomas No.46 Malang 654144 \\ Telp. (0341) 464318-128 Fax. (0341) 460782 \\ e-mail: dini@umm.ac.id ${ }^{\mathrm{a}}$
}

\begin{abstract}
Biomass can be used as an alternative fuel such as making biobriquettes. This study aimed to determine the effect of the comparison of mixtures of banana midrib and corn cobs, the effect of molasses used to obtain biobriquettes according to standards, and the results of chemical and physical analysis of its briquettes. The material used in this study were banana midrib and corn cobs which use molasses as an adhesive. The composition variations used were 100 : 0 to 10:90. The material was dried to the appropriate moisture content then burned to become charcoal. Those charcoal mixed together according to the composition and were added by 50 grams of molasses. It were pressed and dried. Testing of biobriquette characteristics was carried out by testing moisture content, compressive strength, density, ash content, and calorific value. The result of it was the composition of the material 10:90 with a value of $11.18 \%$ moisture content, compressive strength $7,03 \mathrm{~kg} / \mathrm{cm}^{2}$, density $0,70 \mathrm{~g} / \mathrm{cm}^{3}$, ash content $9,18 \%$, calorific value $4724 \mathrm{kal} / \mathrm{g}$.
\end{abstract}

Keywords: biobriquettes, banana midrib, corn cobs, molasses

\section{Pendahuluan}

Bertambahnya jumlah penduduk yang terus meningkat menyebabkan permintaan energi semakin meningkat pula. Sektor energi memiliki peran penting dalam rangka mendukung kelangsungan proses pembangunan nasional [1]. Energi sebagian besar digunakan pada sektor rumah tangga, industri dan transportasi, sedangkan cadangan bahan bakar fosil seperti minyak bumi, gas alam dan batu bara yang selama ini merupakan sumber utama energi jumlahnya semakin menipis [2]. Hal ini menimbulkan terjadinya kelangkaan bahan bakar di masa yang akan dating. Perlu diupayakan sumber energi alternatif lain yang berasal dari bahan baku yang bersifat kontinyu dan dapat diperbaharui seperti energi biomassa.

Biomassa merupakan bahan organik yang dihasilkan baik berupa produk maupun buangan. Sumber energi alternatif dari biomassa yang memiliki potensi adalah limbah kayu, jerami, sekam padi, tongkol jagung, ampas tebu, pelepah pisang, dan kotoran ternak. Biomassa dapat diolah dan dijadikan sebagai bahan bakar alternatif, seperti pembuatan biobriket [3]. Bahan baku yang digunakan pada pembuatan biobriket ini yaitu menggunakan pelepah pisang dan tongkol jagung.

Penelitian dari Wijayanti tentang pembuatan biobriket dari campuran limbah kacang tanah dan kacang mede dengan bahan perekat tetes tebu yaitu dengan cara melakukan karbonisasi dengan tekanan pengepresan sebesar 200 bar dan dikeringkan menggunakan oven dengan suhu $110^{\circ} \mathrm{C}$. Disimpulkan bahwa briket campuran limbah kacang tanah dan kacang mete dengan perekat tetes tebu menghasilkan nilai kalor sebesar 6551,34 kal/gr [4].

Penelitian mengenai pembuatan biobriket menggunakan limbah tongkol jagung sebelumnya pernah dilakukan oleh Hutasoit. Hasil penelitiannya diketahui tongkol jagung memiliki kandungan serat kasar yang cukup tinggi, yakni 33\%, kandungan selulosa sekitar 
$44,9 \%$ dan kandungan lignin $33,3 \%$. Selain itu, nilai kalor yang dihasilkan yakni mencapai $5484,54 \mathrm{kal} / \mathrm{gram}$ kalor sehingga memungkinkan untuk dijadikan biobriket [5].

Pelepah pisang selama ini hanya berakhir sebagai limbah yang digunakan untuk pakan ternak atau mulsa. Pada penelitian ini diupayakan melakukan pencampuran pelepah pisang dan tongkol jagung sebagai biobriket sehingga, meningkatkan manfaat pelepah pisang. Perekat yang digunakan adalah tetes tebu yang merupakan adhesiv alami, sehingga tidak perlu dilakukan pengolahan terlebih dahulu pada proses penambahan perekat. Perekat tetes tebu sendiri diharapkan dapat menambah nilai kalor yang dihasilkan dari briket tersebut. Metode yang digunakan dalam penelitian ini yaitu dengan mencampurkan bahan baku dari pembuatan briket pelepah pisang dan tongkol jagung yang dicampurkan dengan perekat tetes tebu.

\section{MetOde}

\subsection{Alat dan Bahan}

2.1.1 Alat

Alat yang digunakan dalam penelitian ini diantaranya timbangan triple bea mesin kuat tekan, oven listrik, oxygen bomb calorimeter, furnac drum karbonasi, penghalus/penumbuk arang manual, ayakan, wadah pencampuran, cetakan.

\subsubsection{Bahan}

Bahan yang digunakan dalam penelitian ini adalah pelepah pisang, tongkol jagung dan tetes tebu sebagai perekat.

\subsection{Metode}

\subsubsection{Pemilihan bahan}

Bahan baku yang digunakan dalam penelitian ini pelepah pisang dan tongkol jagung serta perekat yang digunakan tetes tebu. Bahan pelepah pisang dan tongkol jagung kemudian di potong kecil-kecil guna untuk mempercepat pengurangan kadar air pada saat di oven nantinya.

\subsubsection{Pengeringan}

Bahan baku yang telah tersedia selanjutnya dikeringkan mengunakan oven yang berguna untuk mengurangi kadar air. Pengeringan ini mengunakan suhu $90^{\circ} \mathrm{C}$.

\subsubsection{Pengarangan/Karbonasi}

Proses karbonasi ini dilakukan untuk mendapatkan arang. Pada proses pembakaran digunakan bahan bakar umpan berupa minyak tanah yang diletakkan ke bagian tengah drum. Pembakaran dari pelepah pisang membutuhkan waktu sekitar 10 - 20 menit untuk menjadi arang. Sedangkan tongkol jagung untuk proses pengarangannya membutuhkan waktu 6 jam. Setelah kedua bahan menjadi arang selanjutnya didinginkan.

\subsubsection{Pengayakan}

Arang yang sudah jadi dihaluskan terlebih dahulu sebelum dilakukan pengayakan. Ayakan yang dipakai berukuran 30 mesh.

\subsubsection{Pencampuran}

Proses pencampuran dari kedua bahan yang sudah menjadi serbuk akan dicampur dengan perekat tetes tebu. Pencampuran ini bertujuan untuk menyatukan bahan arang dan perekat tersebut menjadi satu kesatuan [6]. Jumlah sampel biobriket yang dibuat untuk penelitian ini yaitu sebanyak enak sampel dengan perbandingan bahan dasar yang berbedabeda dimana berat total dari satu briket 30 gram, serta menggunakan perekat tetes tebu sebanyak 50 gram. Ketiga bahan tersebut di aduk merata dengan sistem manual.

\subsubsection{Pencetakan}

Pencetakan briket yang dilakukan pada penelitian ini menggunakan beberapa variasi perbandingan campuran briket yaitu 100 : 0 hingga 10 : 90. Pencetakan ini menggunakan tekanan pengepresan $2 \mathrm{KN} / 203,9 \mathrm{~kg}$. Bentuk cetakan seperti dilihat pada gambar 2.1. 
$50 \mathrm{~mm}$

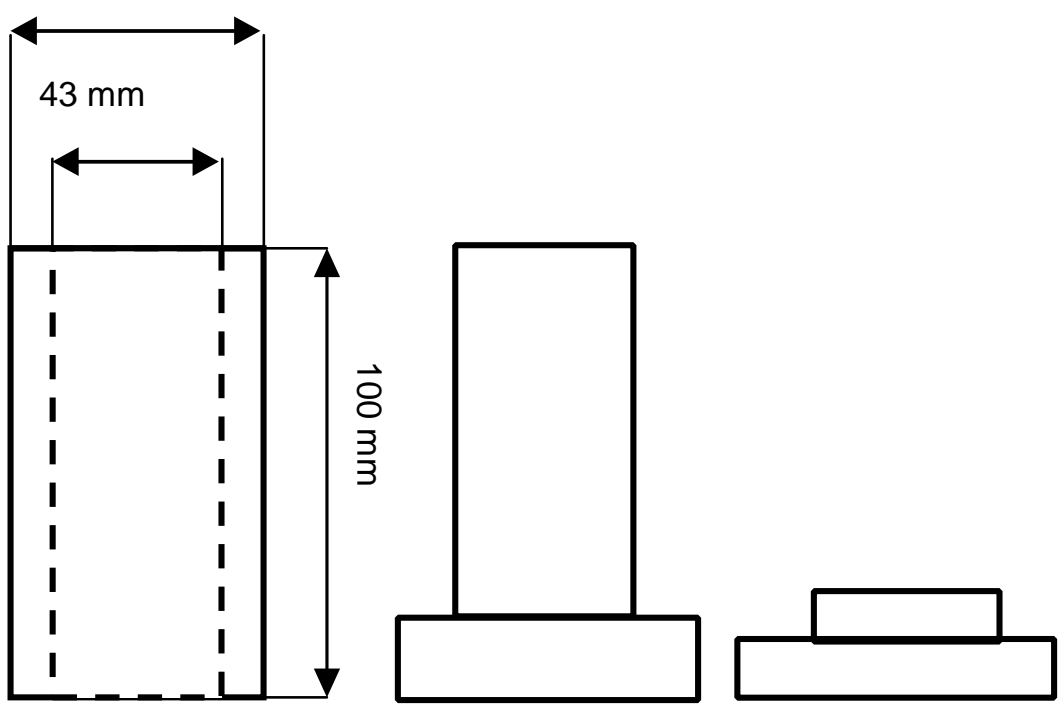

Gambar 2.1 Alat cetak briket

\subsubsection{Pengeringan}

Biobriket yang sudah selesai dicetak lalu dikeringkan menggunakan oven dengan suhu $110^{\circ} \mathrm{C}$ selama 3 jam [7]. Hal ini dilakukan untuk menurunkan kandungan kadar air pada biobriket sehingga dapat digunakan dalam menganalisa bahan tersebut baik fisik maupun kimia.

\subsection{Analisa}

Analisa yang dilakukan pada penelitian ini meliputi kadar air, kadar abu dan kerapatan menggunakan analisa gravimetri, kuat tekan menggunakan alat uji kuat tekan, dan nilai kalor menggunakan analisa bomb kalorimeter.

\section{Hasil dan Pembahasan}

Hasil penelitian yang disajikan adalah nilai dari hasil pengujian pada masing-masing sampel. Hasil dalam penelitian ini meliputi beberapa pengujian diantaranya meliputi kadar air, kuat tekan, kerapatan, kadar abu, nilai kalor.

Tabel 3.1 hasil pembuatan biobriket pelepah pisang dan tongkol jagung

\begin{tabular}{cccccc}
$\begin{array}{c}\text { No } \\
\text { Sampel }\end{array}$ & $\begin{array}{c}\text { Pelepah } \\
\text { Pisang } \\
(\%)\end{array}$ & $\begin{array}{c}\text { Tongkol } \\
\text { Jagung } \\
(\%)\end{array}$ & $\begin{array}{c}\text { Dimensi } \\
(\mathbf{c m})\end{array}$ & $\begin{array}{c}\text { Ukuran } \\
\text { Tinggi } \\
(\mathbf{c m})\end{array}$ & $\begin{array}{c}\text { Massa } \\
(\mathbf{g r})\end{array}$ \\
\hline 1 & 100 & 0 & 4,3 & 4,27 & 77 \\
2 & 90 & 10 & 4,3 & 4,45 & 78,2 \\
3 & 70 & 30 & 4,3 & 4,97 & 77,8 \\
4 & 50 & 50 & 4,3 & 5,35 & 78,9 \\
5 & 30 & 70 & 4,3 & 5,86 & 77,8 \\
6 & 10 & 90 & 4,3 & 6,97 & 79,6 \\
\hline
\end{tabular}

\subsection{Kadar Air}

Kadar air briket merupakan perbandingan berat air yang terkandung dalam briket dengan berat kering setelah dimasukan ke dalam oven Nilai kalor atau panas yang 
dihasilkan oleh briket sangat dipengaruhi oleh kadar airnya. Semakin tinggi kadar air akan semakin rendah nilai kalornya [8].

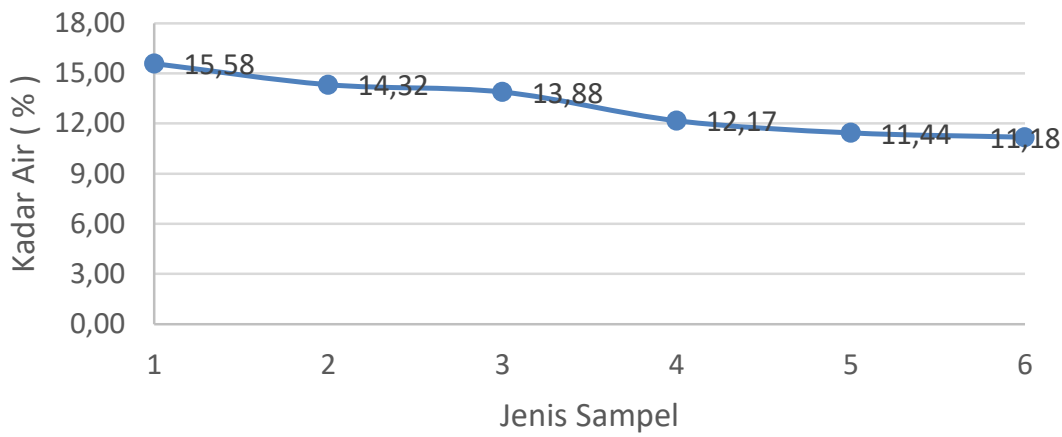

Gambar 3.1 Hubungan antara jenis sampel dengan kadar air

Gambar 3.1 menunjukkan bahwa kadar air tertinggi dimiliki oleh briket sampel 1 dengan komposisi bahan $100 \%$ pelepah pisang dan 0\% tongkol jagung sebesar $15,58 \%$, sedangkan untuk kadar air terendah terdapat pada sampel 6 sebesar 11,18 dengan komposisi bahan $10 \%$ pelepah pisang dan $90 \%$ tongkol jagung. Pengujian ini membuktikan semakin banyak jumlah pelepah pisang yang dimasukkan dalam komposisi biobriket maka akan menyebabkan bertambahnya kadar air. Sebaliknya, semakin banyak tongkol jagung yang ditambahkan ke dalam biobriket maka akan menyebabkan kadar air semakin menurun. Kadar perekat dari tetes tebu yang digunakan pada bahan pelepah pisang dan tongkol jagung juga dapat meningkatkan kadar air. Hal ini dikarenakan kandungan air yang berada pada perekat dan ketidaktahanan dari perekat organik terhadap kelembaban. Banyaknya kadar perekat yang digunakan pada biobriket maka semakin tinggi pula kadar airnya. Semakin tinggi kadar air pada biobriket akan mempengaruhi nilai kalor. Hal ini sesuai dengan penelitian yang dilakukan oleh Prawiswara yang mengatakan bahwa besarnya kadar air dalam biobriket akan mempengaruhi pada nilai kalor yang dihasilkan [9].

\subsection{Kuat Tekan}

Kuat tekan merupakan parameter yang digunakan untuk melihat kualitas fisik daribiobriket. Semakin besar nilai kuat tekan yang dihasilkan oleh biobriket maka, daya tahan atau kekompakkan dari bahan yang digunakan tidak akan mudah pecah.

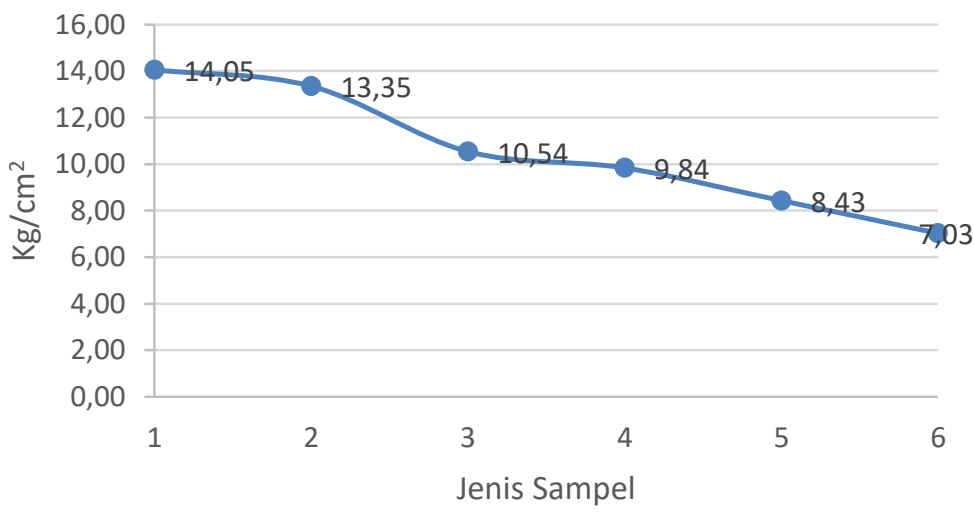

Gambar 3.2 Hubungan antara jenis sampel dengan kuat tekan

Gambar 3.2 menunjukkan hasil pengujian kuat tekan terbaik terdapat pada sampel 1 dengan komposisi 100\% pelepah pisang dan $0 \%$ Tongkol jagung dengan nilai sebesar 14,05 $\mathrm{kg} / \mathrm{cm}^{2}$. Kuat tekan semakin besar dengan bertambahnya presentase pelepah pisang yang 
ada dalam campuran biobriket, sebagaimana sebaliknya, apabila semakin banyak serbuk tongkol jagung, maka akan menghasilkan kuat tekan yang kecil.

\subsection{Kerapatan}

Kerapatan berpengaruh terhadap kualitas briket arang. Besar kecilnya kerapatan dipengaruhi oleh ukuran dan kehomogenan arang penyusun briket arang tersebut. Semakin tinggi keseragaman ukuran serbuk arang, maka akan menghasilkan briket arang dengan kerapatan dan keteguhan yang semakin tinggi pula. Semakin besar tekanan yang digunakan, makin kecil ukuran briket yang dihasilkan,

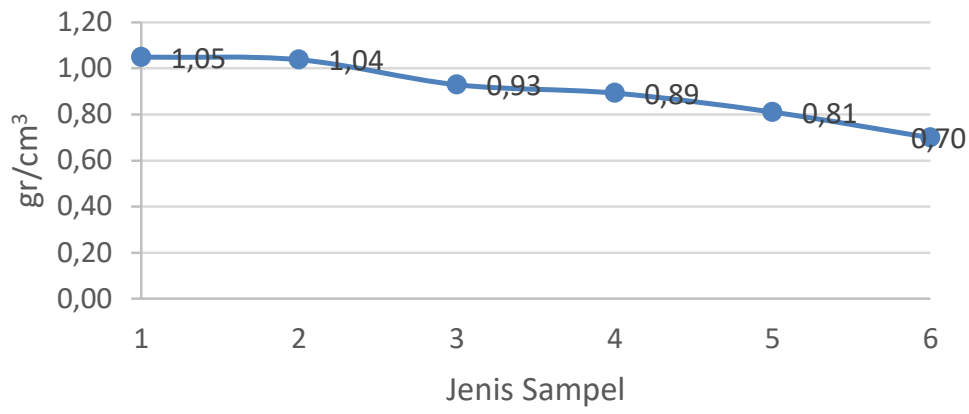

Gambar 3.3 Hubungan antara jenis sampel dengan kerapatan

Pada gambar 3.3 diatas, terlihat bahwa hasil pengujian kerapatan yang diperoleh berkisar $0,70 \mathrm{~g} / \mathrm{cm}^{3}-1,05 \mathrm{~g} / \mathrm{cm}^{3}$. Hasil terbaik briket terdapat pada sampel 1 yang memiliki komposisi bahan $100 \%$ pelepah pisang dan $0 \%$ tongkol jagung sebesar $1,05 \mathrm{~g} / \mathrm{cm}^{3}$. Sedangkan briket yang memiliki kerapatan terendah terdapat pada sampel 6 yang memiliki komposisi bahan $10 \%$ pelepah pisang dan $90 \%$ tongkol jagung sebesar $0,70 \mathrm{~g} / \mathrm{cm}^{3}$. Semakin besar nilai kerapatan pada biobriket, maka nilai kalori yang dihasilkan juga semakin besar. Hal ini sesuai dengan penilitian dari Isa yang menyatakan bahwa kerapatan sangat berpengaruh terhadap nilai kalor yang dihasilkan [10].

\subsection{Kadar Abu}

Kandungan abu merupakan ukuran kandungan material dan berbagai material anorganik di dalam benda uji. Abu adalah bahan yang tersisa apabila biomassa padat dipanaskan hingga berat konstan. Kadar abu ini sebanding dengan kandungan bahan anorganik di dalam biomassa. Salah satu unsur utama yang terkandung dalam abu adalah silika dan pengaruhnya kurang baik terhadap nilai kalor yang dihasilkan [11]. Berikut ini hasil pengujian kadar abu briket seperti ditunjukkan pada Gambar 3.4

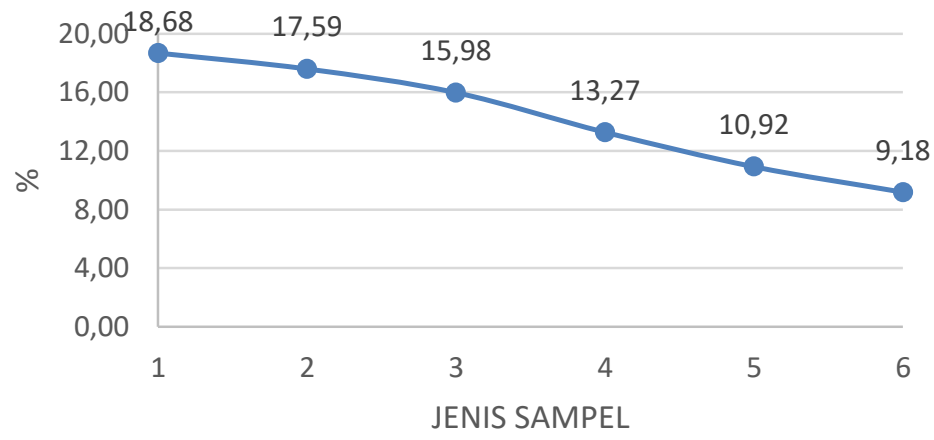

Gambar 3.4 Hubungan antara jenis sampel dengan kadar abu

Pada gambar 3.4 diatas, terlihat bahwa hasil pengujian kadar abu yang diperoleh berkisar $9,18 \%$ - 18,68\%. Hasil terbaik briket terdapat pada sampel 6 yang memiliki 
komposisi bahan $10 \%$ pelepah pisang dan $90 \%$ tongkol jagung sebesar $9,18 \%$. Semakin banyak jumlah pelepah pisang yang dimasukkan pada biobriket, maka akan menyebabkan bertambahnya kadar abu. Sebaliknya, semakin banyak jumlah tongkol jagung yang ditambahkan ke dalam biobriket, maka akan mendapatkan nilai kadar abunya menurun. Hal ini diduga karena jumlah silikat yang dikandung dari arang pelepah pisang lebih besar dibandingkan dengan jumlah silikat yang terkandung oleh tongkol jagung. Konsentrasi perekat molase / tetes tebu juga dapat meningkatkan kadar abu suatu biobriket.

\subsection{Nilai Kalor}

Nilai kalor menjadi parameter mutu paling penting bagi briket arang sebagai bahan bakar sehingga hal itu sangat menentukan kualitas briket arang. Semakin tinggi nilai kalor bakar biobriket arang, semakin baik pula kualitas yang dihasilkan [12]. Berikut ini hasil pengujian nilai kalor briket seperti ditunjukkan pada Gambar 3.5.

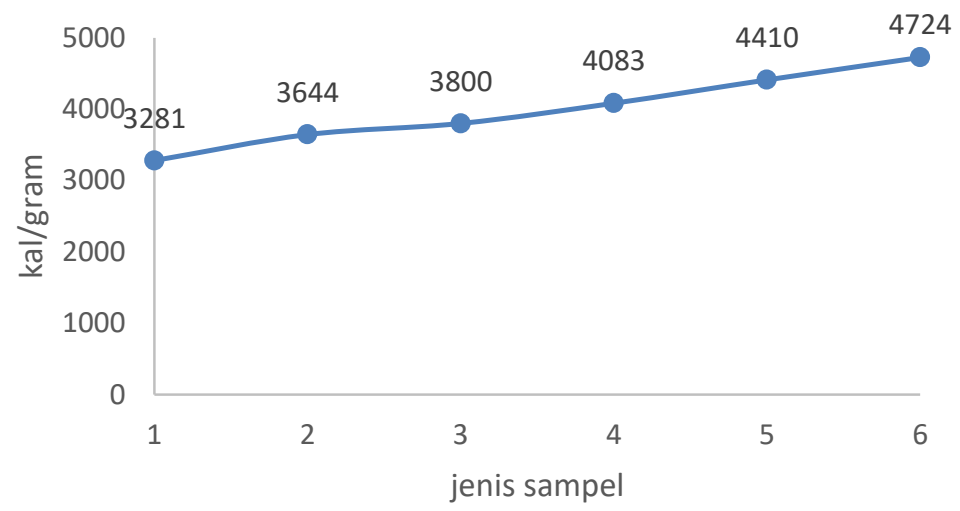

Gambar 3.5 Hubungan antara jenis sampel dengan nilai kalor

Gambar 3.5 diatas dapat dinyatakan bahwa nilai kalor terbaik terdapat pada briket pada sampel 6 dengan komposisi 10\% pelepah pisang dan 90\% tongkol jagung sebesar 4724 $\mathrm{kal} / \mathrm{gram}$. Nilai kalor yang tinggi dipengaruhi oleh kandungan karbon. Konsentrasi perekat tetes tebu juga dapat mengakibatkan nilai kalor tinggi. Hal ini disebabkan kandungan sukrosa yang bisa menjadi sumber karbon sehingga nilai kalor pada briket menjadi naik. Semakin besar kandungan karbon dalam suatu bahan, maka akan baik fungsi bahan tersebut sebagai bahan bakar karena menghasilkan energi yang lebih besar [13].

\section{KeSIMPULAN}

Berdasarkan hasil penelitian dapat disimpulkan bahwa perbandingan komposisi terbaik dalam pembuatan biobriket ini terdapat pada sampel 6 dengan komposisi 10\% pelepah pisang dan $90 \%$ tongkol jagung. Dari pengujian serta analisa fisik dan kimia diperoleh bahwa komposisi tersebut menghasilkan nilai kadar air sebesar $11,18 \%$, kuat tekan sebesar 7,03 $\mathrm{kg} / \mathrm{cm}^{2}$, kerapatan sebesar $0,70 \mathrm{~g} / \mathrm{cm}^{3}$, kadar abu sebesar $9,18 \%$, dan nilai kalor sebesar $4724 \mathrm{kal} / \mathrm{g}$. Briket berbahan dasar pelepah pisang dapat dijadikan sebagai bahan bakar alternatif. Penambahan perekat dari tetes tebu berpengaruh terhadap tingginya nilai kalor.

\section{Daftar Pustaka}

[1] Lubis, A. dan A. Sugiyono. Overview of Energy Planning in Indonesia. Technical Committee Meeting to Asses and Compare the Potential Rule of Nuclear Power and Other Option in Alleviating Health and Enviromental Impacts Electricity Generation.Vienna, Austria. 1996.

[2] Indarti. Indonesia regional seminar on commercialization of biomass technology. 4-8 June, Guangzhou, China. 2001. 
[3] Santosa, dkk. Bisnis Penggemukan Sapi. Jakarta: PT. Agromedia Pustaka. 2012.

[4] Wijayanti Tri. Pembuatan Biobriket Dari Campuran Limbah Kacang Tanah Dan Limbah Kacang Mete Menggunakan Perekat Tetes Tebu. 2008.

[5] Hutasoit, Andreas. Teknologi Pemanfaatan Limbah Tongkol Jagung Menjadi Briket Sebagai Sumber Alternatif. 2013.

[6] Baharudin, A. Fahmi. Pemanfaatan Enceng Gondok sebagai Bahan Baku Pembuatan Briket Arang dan Kanji sebagai Perekat. 2011

[7] Mulia,A. Pemanfaatan Tandan Kosong Kelapa Sawit dan Cangkang Kelapa sawit Sebagai Briket Arang. (2007).

[8] Haygreen JG dan Bowyer JL. Hasil Hutan dan IImu Kayu. Edisi ke-4. Yogyakarta: University Gadjah Mada Press. 1996.

[9] Pramiswara, D.L dan Adiwibowo, P.H. Pembuatan Biobriket Dari Campuran Tongkol Jagung Dan Limbah Bambu Dengan Perekat Tetes Tebu. 2014.

[10] Isa, Ishak. Pelatihan Pembuatan Arang Aktif Pada Masyarakat di Desa Batulayar Kecamatan Bongomeme kabupaten Gorontalo. 2007.

[11] Earl, D.E. A Report on Corcoal. Andre Meyer Reserc Fellow, FAO. Rome. 1974

[12] Ismayana, A. Pengaruh Jenis Kadar bahan perekat pada pembuatan bahan bakar briket blotong sebagai bahan bakar alternatif. 2014.

[13] Noriyati, R.D., Sarwono \& Wahyu, K.A. Kajian Eksperimen Terhadap Karakteristik Pembakaran Briket Limbah Ampas Kopi Instan dan Kulit Kopi (Studi Kasus di Pusat Penelitian Kopi dan Kakao Indonesia. 2012. 